\title{
Working with Small Manufacturing Enterprises: An Analysis of TIDE Demonstration Projects
}

\author{
Len Estrin \\ Bill Anderson \\ Joe Elm \\ Suzanne Garcia \\ John Foreman \\ John Robert \\ Fred Schenker
}

February 2004

TECHNICAL REPORT

CMU/SEI-2004-TR-005

ESC-TR-2004-005 



\title{
Working with Small Manufacturing Enterprises: An Analysis of TIDE Demonstration Projects
}

\author{
ESC-TR-2004-005 \\ Len Estrin \\ Bill Anderson \\ Joe Elm \\ Suzanne Garcia \\ John Foreman \\ John Robert \\ Fred Schenker
}

CMU/SEI-2004-TR-005

February 2004

Technology Insertion, Demonstration, and Execution (TIDE) Program 
This report was prepared for the

SEI Joint Program Office

HQ ESC/DIB

5 Eglin Street

Hanscom AFB, MA 01731-2116

The ideas and findings in this report should not be construed as an official DoD position. It is published in the interest of scientific and technical information exchange.

FOR THE COMMANDER

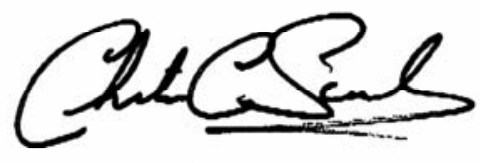

Christos Scondras

Chief of Programs, XPK

This work is sponsored by the U.S. Department of Defense. The Software Engineering Institute is a federally funded research and development center sponsored by the U.S. Department of Defense.

Copyright 2004 by Carnegie Mellon University.

NO WARRANTY

THIS CARNEGIE MELLON UNIVERSITY AND SOFTWARE ENGINEERING INSTITUTE MATERIAL IS FURNISHED ON AN "AS-IS" BASIS. CARNEGIE MELLON UNIVERSITY MAKES NO WARRANTIES

OF ANY KIND, EITHER EXPRESSED OR IMPLIED, AS TO ANY MATTER INCLUDING, BUT NOT LIMITED TO, WARRANTY OF FITNESS FOR PURPOSE OR MERCHANTABILITY, EXCLUSIVITY, OR RESULTS OBTAINED FROM USE OF THE MATERIAL. CARNEGIE MELLON UNIVERSITY DOES NOT MAKE ANY WARRANTY OF ANY KIND WITH RESPECT TO FREEDOM FROM PATENT, TRADEMARK, OR COPYRIGHT INFRINGEMENT.

Use of any trademarks in this report is not intended in any way to infringe on the rights of the trademark holder.

Internal use. Permission to reproduce this document and to prepare derivative works from this document for internal use is granted, provided the copyright and "No Warranty" statements are included with all reproductions and derivative works.

External use. Requests for permission to reproduce this document or prepare derivative works of this document for external and commercial use should be addressed to the SEI Licensing Agent.

This work was created in the performance of Federal Government Contract Number F19628-00-C-0003 with Carnegie Mellon University for the operation of the Software Engineering Institute, a federally funded research and development center. The Government of the United States has a royalty-free government-purpose license to use, duplicate, or disclose the work, in whole or in part and in any manner, and to have or permit others to do so, for government purposes pursuant to the copyright license under the clause at 252.227-7013.

For information about purchasing paper copies of SEI reports, please visit the publications portion of our Web site (http://www.sei.cmu.edu/publications/pubweb.html). 


\section{Table of Contents}

Executive Summary....................................................................................ii

Abstract

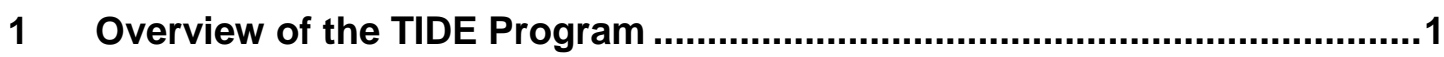

1.1 Organization

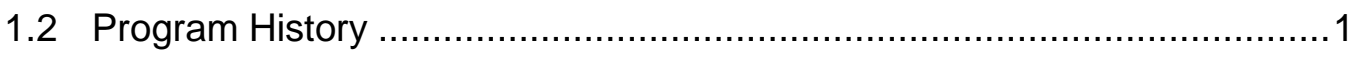

1.3 TIDE Demonstration Projects …………………….........................

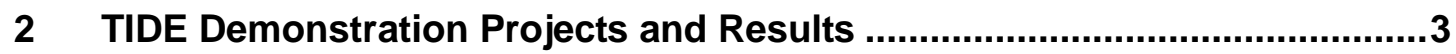

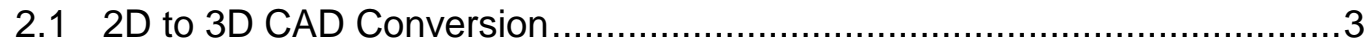

2.2 Integrated MES and Dynamic Scheduling System...................................

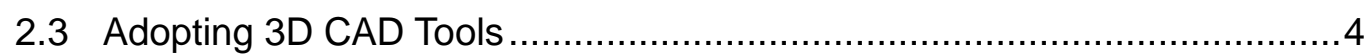

2.4 Adopting a Control System Modeling Tool …………............................

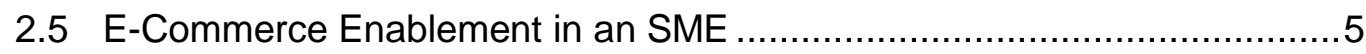

2.6 Application Service Provider Demonstration ...........................................

2.7 Technology Adoption Process Demonstration..........................................

2.8 Unquantifiable Benefits..................................................................

3 Lessons Relating to SMEs..................................................................

3.1 Setting and Managing Expectations …………………………….....

3.2 Lack of Resources Force SMEs to Focus on the Short Term .................... 7

3.3 Process and Progress Take Time and Effort ........................................ 8

3.4 Non-Technology Adoption Barriers Can be Very Challenging .................... 9

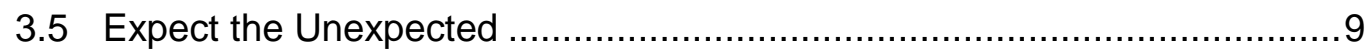

3.6 A Long-Term Commitment Works Best for SMEs.....................................

3.7 "Caveat Emptor" Applies to COTs Software and Vendors ........................10

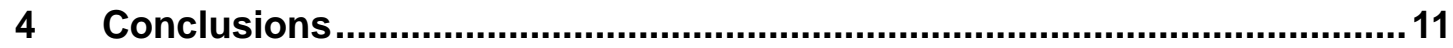

Appendix Congressional Field Testimony ..............................................13

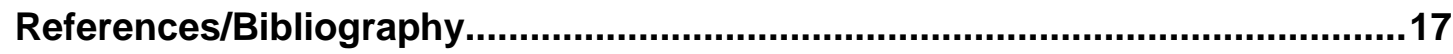




\section{List of Tables}

Table 1: TIDE Demonstration Projects........................................................... 3 


\section{Executive Summary}

Small manufacturing enterprises (SMEs) are vital to the defense industrial sector. In addition to providing vitally needed fabrication services, they supply increased production capacity at times of strategic need, and they contribute to the economic strength of the nation. However, many SMEs have not adopted the advanced software technologies required to support the defense industry and to achieve competitiveness in a global marketplace. The Technology Insertion, Demonstration, and Evaluation (TIDE) Program was established to help correct this situation. According to the Defense Appropriations Act that established the program, the objective of TIDE is to "demonstrate the cost savings and efficiency benefits of applying commercially available software and information technology to the manufacturing lines of small defense firms..." [DoD 99].

Over three years, the TIDE Program achieved that mission. It showed that advanced software technologies can help even very small manufacturing enterprises increase quality, reduce turnaround time, and improve productivity and profitability. At the same time, the TIDE Program identified the challenges and risks facing programs or organizations trying to help SMEs. This paper documents some of those challenges and risks, and presents recommendations to address them. The report is organized as follows: Chapter 1 describes the TIDE Program; Chapter 2 describes the demonstration projects and results; and Chapter 3 presents lessons related to SMEs. 
CMU/SEI-2004-TR-005 


\section{Abstract}

This paper documents some of the challenges and risks facing programs or organizations trying to help small manufacturing enterprises (SMEs). The Technology Insertion, Demonstration, and Evaluation (TIDE) Program performed seven demonstration projects with SMEs. While the companies differed in size, technology needs, and in-house capabilities, they are typical of the companies to be found in the SME sector. This report examines the effort to help SMEs through demonstration projects. It describes the challenges that the TIDE Program personnel faced, and presents recommendations to help organizations in similar situations address or avoid those challenges. 



\section{Overview of the TIDE Program}

\subsection{Organization}

The TIDE Program is managed by the Carnegie Mellon ${ }^{\circledR}$ Software Engineering Institute (SEI). In addition, the Institute for Economic Transformation (IET) at Duquesne University, the National Institute of Standards and Technology (NIST), Southwestern Pennsylvania Industrial Resource Center (now Catalyst Connection), and the H. J. Heinz School of Management and Public Policy at Carnegie Mellon University partnered with the SEI to accomplish various tasks.

\subsection{Program History}

In the spring of 1998, United States Congressman Mike Doyle hosted a technology summit in Pittsburgh. Leaders from the manufacturing, community development, and high technology sectors met to identify ways to strengthen the economic base of western Pennsylvania. The participants discussed many topics, including the need for small manufacturing enterprises (SMEs) to adopt advanced software technologies to improve their competitiveness and their ability to support the defense industry.

Based on information obtained during that summit, Congressman Doyle sponsored the Technology Insertion, Demonstration, and Evaluation (TIDE) Program. TIDE was designed to "demonstrate the cost savings and efficiency benefits of applying commercially available software and information technology to the manufacturing lines of small defense firms" [Doyle-TIDE 00].

To achieve the mission of the TIDE Program, the SEI developed a three-pronged strategy of demonstration projects, workforce development, and technology development initiatives. The TIDE technology demonstration projects showcased advanced software tools. The TIDE workforce development initiative offered workshops, courses, and presentations on technology adoption and integration. The TIDE technology development initiative focused on inserting advanced software tools into the business processes of SMEs. Of the three initiatives, the demonstration projects required the greatest allocation of resources, and became the main focus of the TIDE Program.

() Carnegie Mellon is registered in the U.S. Patent and Trademark Office. 


\subsection{TIDE Demonstration Projects}

The demonstrations projects had a number of objectives. As originally conceived by TIDE personnel, the projects were designed to highlight capabilities, to obtain unbiased data on return on investment (ROI) and other benefits, and to document the steps needed to adopt advanced software.

To determine which demonstration projects to conduct, the TIDE Program solicited proposals from small manufacturers throughout the region. These were companies that employed less than 500 workers and had revenues below $\$ 5 \mathrm{M} .{ }^{1}$ The firms also had characteristics typical of SMEs, such as highly centralized structures, limited financial resources, generalist employees instead of specialists, and informal rules and infrastructures [Thong 97].

Ultimately, the TIDE Program worked with four such companies:

- Carco Electronics manufactures multi-axis rotational devices used to test inertial navigation and missile-seeker systems. The company, which was spun off from a large corporation several years ago, employs approximately 70 people total. $^{2}$

- The Kurt J. Lesker Company manufactures ultra-high vacuum components and systems for a wide range of commercial and research applications. The family-owned company has 230 employees.

- Magdic Precision Tool both designs and manufactures compaction tooling for the powdered metal industry. The family-owned company has 20 employees.

- Mitchell and Westerman Inc. manufactures pallets and skids. The company employs six workers.

From 2000 to 2003, the TIDE Program conducted seven demonstration projects with these firms. In exchange for technical assistance, the companies opened their records, processes, and facilities so that TIDE researchers and staff members could document return on investment and other software technology issues. The projects and their results are described in the next section.

1 A small business is defined by the Small Business Administration in the Federal Register (Title 13, Chapter 1, and Part 121). The definition also appears in the Federal Acquisition Regulation (19.101). Depending on the type of product called for by the contract, a company may qualify as a small business as long as it, or its affiliates, does not employ more than a specified number of employees (usually not more than 500, 750, or 1,000). For construction and some service industries, the criterion is a specified annual dollar volume of sales or receipts rather than the number of employees [NACFAM 02].

2 Carco had two map locations, Pittsburgh and California, with each employing about the same number of people. 


\section{TIDE Demonstration Projects and Results}

The seven demonstration projects included both discrete projects and projects that built upon earlier work. The projects are presented in Table 1. Details of the projects are described in the following paragraphs.

Table 1: TIDE Demonstration Projects

\begin{tabular}{|l|l|l|}
\hline Company Name & Project & Description \\
\hline $\begin{array}{l}\text { Kurt J. Lesker } \\
\text { Company }\end{array}$ & $\begin{array}{l}\text { 2D to 3D Computer-Aided Design } \\
\text { (CAD) Conversion }\end{array}$ & $\begin{array}{l}\text { Upgrade from mechanical drafting to solid } \\
\text { modeling capability }\end{array}$ \\
\hline $\begin{array}{l}\text { Kurt J. Lesker } \\
\text { Company }\end{array}$ & $\begin{array}{l}\text { Integrated Manufacturing Execution } \\
\text { System (MES) and Dynamic Schedul- } \\
\text { ing System }\end{array}$ & Improve production planning capabilities \\
\hline Carco Electronics & Adopting 3D CAD tools & $\begin{array}{l}\text { Improve mechanical design and engineering } \\
\text { capabilities }\end{array}$ \\
\hline Carco Electronics & $\begin{array}{l}\text { Adopting a Control System Modeling } \\
\text { Tool }\end{array}$ & $\begin{array}{l}\text { Improve electronic design and engineering } \\
\text { capabilities }\end{array}$ \\
\hline $\begin{array}{l}\text { Magdic Precision } \\
\text { Tooling }\end{array}$ & E-Commerce Enablement in an SME & $\begin{array}{l}\text { Improve throughput and customer responsive- } \\
\text { ness }\end{array}$ \\
\hline $\begin{array}{l}\text { Mitchell and } \\
\text { Westerman }\end{array}$ & $\begin{array}{l}\text { Testing Application Service Provider } \\
\text { (ASP) Paradigm }\end{array}$ & $\begin{array}{l}\text { Use ASP to obtain manufacturing execution } \\
\text { capability }\end{array}$ \\
\hline Carco Electronics & Kinematics Software Selection & $\begin{array}{l}\text { Assess and select software to fit current } \\
\text { CAD/CAE capabilities }\end{array}$ \\
\hline
\end{tabular}

\subsection{D to 3D CAD Conversion}

To help the Kurt J. Lesker Company (KJLC) achieve its business goal, management decided to upgrade from a two-dimensional (2D) mechanical drafting tool to a three-dimensional (3D) Computer-Aided Design (CAD) package. TIDE personnel worked with KJLC employees to assess business processes, define company needs based on current requirements and strategic business goals, evaluate commercial products, select the most appropriate package, and deploy the software.

Results: The move from a 2D mechanical drafting tool to a 3D CAD package allowed Lesker to design families of products rather than design and build each product from scratch. 
According to CEO Kurt Lesker, the effort helped the company to achieve an ROI within the first year by

- cutting lead times by $35 \%$

- reducing engineering hours per job from 500 to 50

- reducing production hours per project from 350 to 100

- increasing production capacity three-fold without additional personnel

\subsection{Integrated MES and Dynamic Scheduling System}

TIDE personnel are working with KJLC to adopt a commercial manufacturing execution system (MES) capable of producing bills of material, process routings, resource management, and traceability from receipt of orders through shipping.

TIDE personnel are integrating a dynamic scheduling tool with the MES. The dynamic scheduler was originally developed to help the U.S. Air Force manage aircraft and crews, and was modified for the manufacturing domain. Once it has been integrated, the dynamic scheduler will enable users to accurately predict delivery dates, understand the impact of a schedule change, and update the schedule as events occur. This, in turn, will help them to increase shop floor capacity and throughput, reduce non-value-added time, and reduce work in progress.

Results: The dynamic scheduling tool has been demonstrated and is in a beta state. When fully developed, commercial availability is expected.

\subsection{Adopting 3D CAD Tools}

Carco Electronics needed to improve its engineering capabilities and customer responsiveness in order to compete against much larger firms. TIDE personnel helped them to upgrade their existing 3D CAD system and local area network integrate a finite element analysis (FEA) tool, and modify their work processes for the new capabilities [Robert 03].

Results: The 3D Solid Modeling and FEA tools helped Carco to reduce

- mechanical design errors by $90 \%$

- mechanical assembly rework by $25 \%$

- mechanical assembly time by $15 \%$

- stress analysis cost by $30 \%$

- mechanical drafting time by $25 \%$

- elapsed time for stress analysis by $50 \%$ 
- total engineering cycle time by $10 \%$

As a result, Carco achieved a $100 \%$ return on investment, and an actual cost savings of $\$ 135,000$ in its first year.

\subsection{Adopting a Control System Modeling Tool}

TIDE also helped Carco to use advanced software to reduce the risk and cost of developing new products. The Carco-TIDE team implemented a computer-aided engineering (CAE) tool set. It eliminated the need to physically prototype and test design iterations. Instead, Carco personnel were able to develop the control system, simulate and analyze its performance, and model control system-device integration throughout the product development life cycle using the software. The simulation tool included links to electronic design automation (EDA) tools that simplified implementing the design in hardware and software.

Results: Using the toolset, company engineers significantly reduced new product development costs, earning an ROI of five to one on the first project alone. Carco engineers also used the software tool to develop and patent a new control algorithm and to generate additional revenue to support the new product development effort.

\subsection{E-Commerce Enablement in an SME}

Magdic Precision Tooling, Inc. needed to improve throughput by reducing product-delivery cycle time. To achieve this goal, TIDE personnel helped the company implement a manufacturing execution system (MES) with e-commerce capability. The system automates quotegeneration, order-processing workflow management, performance analysis, and accounting functions. It features a Web-viewer tool that enables customers to review the status of their orders online. The system offers Magdic a virtually paperless manufacturing capability.

Results: The system enabled Magdic to

- increase shop capacity by $10 \%$

- reduce engineering change turnaround $50 \%-70 \%$

- reduce repeat order entry time by $25 \%$

- save machine operators 30-60 minutes each day in document search time

\subsection{Application Service Provider Demonstration}

Many small manufacturers would like to implement an MES, but are concerned about the price and complexity. To address this issue, the TIDE Program is working with Internet service provider Stargate Industries and Shoptech Industrial Software Corporation to offer an 
online MES. In this paradigm, manufacturers purchase capabilities, rather than the entire package. Mitchell and Westerman, Inc., is testing the online MES and ability of the application service provider (ASP) paradigm to serve this market. The SME initially expressed a number of concerns, including data integrity and safety, accessibility, and cost.

Results: After several months of testing, the network safety features of the Internet provider and the security features of the MES software appear satisfactory. In response to concerns about accessibility, the Internet provider supplied a dial-up line as a backup to the DSL capability. At this point, the cost to the SME appears acceptable. The Internet provider is also comfortable with the pricing structure. It remains to be seen whether the MES vendor can deliver the software online and still make a profit.

\subsection{Technology Adoption Process Demonstration}

To demonstrate its ability to apply the TIDE methods on its own, Carco Electronics assessed software applications to complement its CAD and CAE packages. Applying the experienced gained with the initial TIDE demonstration project, Carco engineers assessed their strategic business goals and immediate engineering needs. Based on that assessment, they identified kinematics software as the most appropriate means of enhancing their current CAD and CAE capabilities. Carco engineers then developed a list of candidate vendors, reviewed their offerings, selected the most appropriate package, and successfully negotiated with the vendor.

Results: Using their newly acquired technology adoption process knowledge, Carco engineers turn the entire project around in half the time that it ordinarily would have taken.

\subsection{Unquantifiable Benefits}

In general, the productivity data captured during the demonstration projects proved the ability of advanced software to "pay for itself." In addition to the financial and productivity benefits, all the TIDE participants reported improved unquantifiable benefits, such as

- better decision making

- better planning

- improved ability to collaborate with customers and suppliers

- enhanced innovation

- improved employee morale

The technology demonstration projects also led to additional technology adoption efforts, as companies began looking for ways to take advantage of their new capabilities. In essence, the technology demonstration projects began a series of continuous improvement activities. 


\section{Lessons Relating to SMEs}

During the demonstration projects, TIDE personnel learned a number of lessons that can benefit any organization planning to work with SMEs. A detailed description of these lessons follows.

\subsection{Setting and Managing Expectations}

Over the course of three years, TIDE Program personnel met with dozens of SME managers. Some of these meetings came as a result of requests for proposals (RFPs) for the demonstration projects. Most SME managers assumed that the TIDE Program would supply "free" technical support (e.g., hardware, software, ongoing consulting, and/or access to government business.) Even when managers were told that they must be responsible for certain activities as part of the effort, they assumed that TIDE personnel would do the work for them. Organizations planning to work with SMEs should document managers' understanding of the project, identify actions to be performed, and obtain managers' commitment to scheduled milestones in order to avoid confusion and finger pointing.

\subsection{Lack of Resources Force SMEs to Focus on the Short Term}

Many of the SMEs that participated in the TIDE Program were struggling to stay in business. ${ }^{3}$ (One TIDE participant simply shut its doors rather than continue the struggle.) These companies were not necessarily poorly run or unprofitable. Rather they were limited by the financial, managerial, and human resources available. This affected the TIDE effort in many ways.

For example, most SME managers had little or no managerial backup. This limited their ability to meet and/or to visit other locations. When meetings were scheduled, managers often had to postpone them to handle a sudden job order or a problem. The constant need to "fight fires" also made it difficult for managers to remain committed to TIDE demonstration projects. Once their focus was turned to other issues, progress typically stopped. As a result,

3 Appendix A contains testimony delivered by Joe Magdic, President of Magdic Precision Tooling, on the topic of SMEs' survival. Magdic, a participant in the TIDE Program, delivered the testimony before a Congressional Field Forum. 
TIDE personnel had to constantly "resell" their technology demonstration projects and promote both the short-term and the long-term strategic benefits that would result. ${ }^{4}$

The lack of financial resources made it difficult for managers to shift their attention from short-term issues and engage in long-term, strategic planning. Similarly, the lack of available and experienced employees placed additional pressure on TIDE personnel to step in and contribute expertise in situations where TIDE personnel wanted to act as observers.

Organizations planning to work with SMEs must be sensitive to SME resource limitations when defining the scope of a project.

\subsection{Process and Progress Take Time and Effort}

Even under the best of circumstances, the demonstration projects typically took more time and effort than either the SME or the TIDE program had predicted. As a federally funded research and development corporation (FFRDC), the SEI had to follow the proper procedures for purchasing equipment and formalizing the relationship with SMEs. This frustrated SME managers who mistakenly assumed that TIDE personnel would deliver software or hardware to their door as soon as their company signed up for the TIDE Program. This attitude indicates that they did not understand the complexity of the SEI/TIDE-SME relationship or the time and effort involved in technology adoption.

If SME managers felt that the SEI moved slowly, TIDE personnel often felt the same way toward the SMEs. Nearly every process improvement methodology starts by understanding the current state and defining the goals for the future state. However, SMEs tend to operate more on "tribal knowledge" rather than formal procedures. As a result, assessing their current state was both challenging and time consuming. Part of the challenges was that SMEs lacked to resources to carry out the required activities. However, in many instances, the SMEs lacked the required knowledge. Often, TIDE personnel had to support this effort to move the project along. One SME felt that process changes arising from this better understanding of current processes were more beneficial than the introduction of the new technology.

Organizations planning to work with SMEs must set realistic schedules and milestones, be able to show what SMEs must do and how to do it, and provide reasonable support in order to keep projects moving.

$4 \quad$ It is revealing to note that none of the SME managers would have attempted the improvement projects on their own. The fact that the TIDE Program was there to support them made the difference. This says a great deal about the need for programs like TIDE. 


\subsection{Non-Technology Adoption Barriers Can be Very Challenging}

The TIDE Program was focused on helping SMEs adopt technology. In order to achieve that goal, TIDE personnel had to address a number of barriers. Technology barriers included the lack of up-to-date equipment or training in advanced software. Yet TIDE personnel also faced non-technology adoption barriers, such as cultural and organizational issues. For example, when one company made advanced software available to junior-level draftsmen, seniorlevel engineers resented what they viewed as a loss of power. Company managers eventually resolved the conflict by giving draftsmen a "light" version of the software. In another case, TIDE personnel had to conduct an in-house technology adoption workshop to get everyone synchronized with company activities.

Organizations must be prepared to help SMEs address cultural, organization, and other nontechnical barriers to the success of their project.

\subsection{Expect the Unexpected}

Unexpected issues affected the TIDE Program. For example, while one SME was evaluating a new integrated manufacturing execution system under the TIDE Program, its existing MES crashed. Rather than attempt to recover the old system, the SME elected to switch over to the TIDE MES. This prevented TIDE personnel from documenting a "normal" transition between systems, a paradigm that would be applicable to a wider class of technology adoptions.

In another instance, cash flow problems almost put one SME out of business in the middle of the TIDE Project. The CEO spent a lot of time negotiating with his board of directors, with creditors, with lenders, and with the customers to keep the company going, even though the company was "doing well." The lesson for any organization involved in a similar effort is to be aware of the dynamic nature of SME operations, and plan for the unexpected by allocating time, funding, and personnel resources for such contingencies.

\subsection{A Long-Term Commitment Works Best for SMEs}

As mentioned earlier, the goal of the TIDE Program was to help SMEs move along the technology curve (i.e., "teach people how to fish"). However, some SMEs displayed a tendency to revert to their old ways and old focus once a project was over. To help SMEs break their old habits, it was (and still is) necessary to stay involved. TIDE follow-on projects helped provide this momentum. For example, TIDE encouraged Carco to add capabilities to the software the company had previously adopted. Under the watchful eyes of TIDE personnel, Carco engineers followed the methods previously demonstrated by the TIDE staff. The engineers reviewed their requirements, identified the capabilities that they required, surveyed 
available packages, chose a particular software kit, negotiated with the vendor, and installed the capability. It remains to be seen whether the momentum will continue at Carco or any of the other SMEs that participated in the TIDE Program.

\section{7 "Caveat Emptor" Applies to COTS Software and Vendors}

To choose a vendor, TIDE and SME team members identified candidates, surveyed the literature, and interviewed sales personnel and select customers. They also followed an approach based on the Analytical Hierarchical Process [[Anderson 02]. This process used pair-wise comparisons to prioritize and evaluate requirements for software. In the process, TIDE personnel also used sensitivity analyses to see how changes could affect outcomes. The effort identified the most appropriate software based on the information available. However, vendors often exaggerated the capabilities of their software and/or their expertise. In one particular case, the vendor claimed to have a capability before it was released. To avoid this situation, TIDE personnel suggest visiting customer sites, if possible, to see the software in action before committing to it.

Similarly, the quality of vendor-supplied training varied widely. Some trainers only went by the book. This approach caused a number of delays and missteps, as TIDE personnel and SMEs tried to work with the limited, and in some cases, incomplete information the trainers provided. The key is to find someone who not only knows the software, but who knows the application. This type of domain expert can make a significant difference towards a positive outcome. 


\section{Conclusions}

The TIDE demonstration projects showcased how advanced software can strengthen SMEs' ability to support the defense industry by improving their productivity, quality, and responsiveness. However, moving SMEs along the technology curve required effort in a number of different areas. In addition to providing hardware, software, and network support, TIDE personnel had to supply business process re-engineering and technology adoption support as well. Organizations planning to work with SMEs must be prepared to take on a variety of roles during the course of their technology adoption projects. 
CMU/SEI-2004-TR-005 


\section{Appendix: Congressional Field Testimony}

Testimony by Joe Magdic to the Northeast-Midwest Congressional Coalition Manufacturing Forum held at Carnegie Mellon University, July, 2003, is below:

"First of all, I would like to thank you for the opportunity to speak today. I am hoping that I can give you some insight into the challenges that many small businesses are facing in today's economy.

I am not an expert on global markets and economics. I'm just a small businessman working in the trenches. My father, Ted Magdic, formed Magdic Precision Tooling back in 1981. We started out in the corner of someone else's shop with a few machines and only one customer. My mother had to work near a noisy air compressor while she did the books but she did not complain. In 1983, we moved to our current location in East McKeesport where we have enjoyed many successful years and where my mother had her own quiet office. She is now happily retired and only slightly hearing impaired and a little worried for the current generation.

When I took over the firm in 1993, I began investing in our future by upgrading almost every aspect of our operation. This enabled us to produce more and we began to grow in leaps and bounds. Today, we are a lean and technologically up to date company. Our 17 employees are very dedicated and talented people who are using all of the latest tools available in modern manufacturing. In spite of all this, we are struggling. More and more, I see companies failing and hard-working Americans losing their jobs. I see my own employees struggling to maintain their lifestyle because their pay increases cannot match the pace of increasing energy and food costs. And I see an increasing number of jobs leaving our soil and going to foreign countries. As a result, I cannot help but be concerned for our future.

Here are some examples of what we are facing right now.

1. Customers are increasingly demanding price cuts. Twice in recent years, our largest customer has asked for across the board price cuts. Another customer continually asks for price matching to a low cost vendor even though our quality is superior to the low cost vendor. 
2. Customers are stretching out their payments. They don't pay their bills in 30 days any more and many expect us to bankroll them for as long as 6 months. This has put a severe strain on our cash flow.

3. Customers are demanding more and more value added services like engineering and design and they are saying the same thing as the Bank of America commercial: "By the way, we don't want to pay for that either." They expect it and they get it because we are not going to let them walk away and go somewhere else.

4. Last year a customer ran up a repair bill close to $\$ 50,000$ and then declared bankruptcy. The customer reorganized and re-entered the market with no obligation to even attempt to make me whole. Somehow bankruptcy seems to have become an acceptable normal business practice to restructure debt.

5. Our health care costs are going up in large chunks. We recently dropped Select Blue and switched to Health America because of a $20 \%$ increase. Other costs of doing business that we cannot control are continually increasing (such as utilities, taxes, equipment repair). In the meantime the amount we can charge for our product has remained very flat over the last several years, yet somehow we are managing to survive.

6. I do not compete directly with foreign companies. However, my customers compete and they are finding it very difficult to succeed. For example, one of our customers bid against an Asian firm and found that he could not even obtain the material for the cost they were selling the part. It is extremely hard to beat firms that are paying employees pennies an hour.

7. There's another issue. Foreign firms have access to U.S. markets for their products, but from what I understand, we do not have the same access/opportunity in their markets. This takes jobs away from American producers and their supply chain partners. One customer found that it was cheaper to purchase the foreign product outside the country and resell it in America than it was to manufacture it. That customer's decision cost us $\$ 20,000$ a year in lost business. I was shocked by this particular incident because we were never asked if there might be a cheaper way to make the part. They just assumed it would be too expensive.

In spite of all this, I still feel optimistic about the opportunities for my company, providing that the situation does not get worse. I would like to see a continuation of government programs to help small business.

Let me take a moment to speak about one such program. It is called Technology Insertion, Demonstration, and Evaluation Program, or TIDE for short. Since we became involved with the program in 2002, my company has improved productivity due to the technology that we were able to implement. The TIDE program helped us choose the right software package for our company. They guided us through a thoughtful process that helped eliminate some of the trial and error in making such an important choice. TIDE helped us to streamline our paper flow by enabling us to electronically display all of our drawings. This helped our business in 
many areas and cut wasted time due to lost or damaged drawings. It also enabled more parallel processing to occur in our operation, since different departments could view the same drawings in many different locations. This type of sharing and collaboration was not possible before. In fact, the software affects virtually every aspect of the operation, from customer service and accounting all the way through to the shop floor. We went from having a slow, cumbersome and crash-prone system that nobody wanted to use, to a system that the employees and management can now use as a speedy, helpful, and reliable tool.

In addition to TIDE, we have benefited from another important program called Manufacturing 2000. This program provided training in basic machining skills and helps provide a pool of people we can hire from. It helps to cut down HR costs by pre-screening prospective employees and training them at a minimal cost to the company hiring the employee. We have taken advantage of this program in the past and plan to use it more in future.

In conclusion, I feel that more can be done to help our economy. I would like to see our government make sure that the playing field is level and that U.S. companies have the same access to foreign markets as they have to ours. Perhaps the government can provide incentives for U.S. companies to buy American when possible. Perhaps the average American needs to be educated on what it means to buy cheap imported products and how this will eventually affect their day-to-day lives. I realize that it is all about supply and demand but perhaps this needs to be tempered with some common sense. For the time being, I believe that America's small businesses can compete but I really wonder how much longer we can hold out if the current trends continue." 


\section{References/Bibliography}

All URLs are valid as of the publication date of this document.

[Anderson 02] Anderson, B. \& Buhman C. Technology Selection and Adoption Processes. Pittsburgh, PA: Carnegie Mellon University, Software Engineering Institute, 2002. <http://www.sei.cmu.edu/tide/publications/2002presentations/ anderson-buhman/tsld001.htm $>(2002)$.

[DoD 99] Department of Defense. Department of Defense Appropriations Act 2000. Washington DC: $106^{\text {th }}$ Congress, 1999.

[Doyle-TIDE 00] Doyle-TIDE Program <http://www.house.gov/doyle/tide.html> (2000).

[NACFAM 02]

National Coalition for Advanced Manufacturing. "Contributions of and Issues Concerning Small and Medium Sized Manufacturers in the Defense Industrial Base.” Washington, DC: NACFAM, 2002. <http://www.nacfam.org/sme_concept.pdf> (2002).

[Robert 03]

Robert, J. \& Elm, J. Integration of CAD and FEA tools in a Small Manufacturing Enterprise (CMU/SEI-2003-TR-015). Pittsburgh, PA: Software Engineering Institute, Carnegie Mellon University, 2003. <http://www.sei.cmu.edu/publications/documents /03.reports/03tr015.html $>$ (2003).

[Thong 97]

Thong, J. Y. L. \& Yap, C. S. "Effects of Resource Constraints on Small Business," 191-206. International Working Conference on Diffusion, Adoption and Implementation of Information Technology. Ambleside, UK, June 25-27, 1997. London, UK: Chapman \& Hall, 1997. 



\begin{tabular}{|c|c|c|c|c|}
\hline \multicolumn{3}{|c|}{ REPORT DOCUMENTATION PAGE } & \multicolumn{2}{|c|}{$\begin{array}{l}\text { Form Approved } \\
\text { OMB No. 0704-0188 }\end{array}$} \\
\hline \multicolumn{5}{|c|}{ 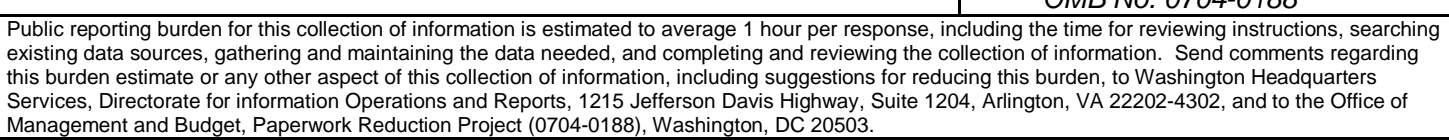 } \\
\hline $\begin{array}{l}\text { AGENCY USE ONLY } \\
\text { (Leave Blank) }\end{array}$ & \multicolumn{2}{|l|}{$\begin{array}{ll}\text { 2. } & \text { REPORT DATE } \\
& \text { February } 2004\end{array}$} & \multicolumn{2}{|c|}{$\begin{array}{l}\text { 3. REPORT TYPE AND DATES COVERED } \\
\text { Final }\end{array}$} \\
\hline \multicolumn{3}{|c|}{$\begin{array}{l}\text { Working with Small Manufacturing Enterprises: An Analysis of TIDE } \\
\text { Demonstration Projects }\end{array}$} & \multicolumn{2}{|c|}{ F19628-00-C-0003 } \\
\hline \multicolumn{5}{|c|}{$\begin{array}{ll}\text { 6. } & \text { AUTHOR(S) } \\
& \text { Len Estrin, Bill Anderson, Joe Elm, Suzanne }\end{array}$} \\
\hline \multicolumn{3}{|c|}{$\begin{array}{l}\text { PERFORMNG ORGANZATONNAME(S) AND ADDRESS(ES) } \\
\text { Software Engineering Institute } \\
\text { Carnegie Mellon University } \\
\text { Pittsburgh, PA } 15213\end{array}$} & \multicolumn{2}{|c|}{$\begin{array}{ll}\text { 8. } & \text { PERFORMNG ORGANIZATION } \\
\text { REPORT NUMBER } \\
\text { CMU/SEI-2004-TR-005 }\end{array}$} \\
\hline \multicolumn{3}{|c|}{$\begin{array}{l}\text { 9. SPONSORING/MONTORING AGENCY NAME(S) AND ADDRESS(ES) } \\
\text { HQ ESC/XPK } \\
5 \text { Eglin Street } \\
\text { Hanscom AFB, MA 01731-2116 }\end{array}$} & \multicolumn{2}{|c|}{$\begin{array}{l}\text { 10. SPONSORING/MONTOFING AGENCY } \\
\text { REPORT NUMBER } \\
\text { ESC-TR-2004-005 }\end{array}$} \\
\hline \multicolumn{5}{|c|}{ 11. SUPPLEMENTARY NOTES } \\
\hline \multicolumn{3}{|c|}{$\begin{array}{l}\text { 12A DISTRIBUTIONAVVALABIUTYSTATEMENT } \\
\text { Unclassified/Unlimited, DTIC, NTIS }\end{array}$} & \multicolumn{2}{|c|}{ 12B DISTRIBUTIONCODE } \\
\hline \multicolumn{5}{|c|}{$\begin{array}{l}\text { 13. ABSTRACT (MAXIMUM 200 WORDS) } \\
\text { This paper documents some of the challenges and risks facing programs or organizations trying to help small } \\
\text { manufacturing enterprises (SMEs). The Technology Insertion, Demonstration, and Evaluation (TIDE) Program } \\
\text { performed seven demonstration projects with SMEs. While the companies differed in size, technology needs, } \\
\text { and in-house capabilities, they are typical of the companies to be found in the SME sector. This report exam- } \\
\text { ines the effort to help SMEs through demonstration projects. It describes the challenges that the TIDE Pro- } \\
\text { gram personnel faced, and presents recommendations to help organizations in similar situations address or } \\
\text { avoid those challenges. }\end{array}$} \\
\hline \multicolumn{3}{|c|}{$\begin{array}{l}\text { SUBJECT TEPMS } \\
\text { demonstration project, SME, small manufacturing enterprise, CAD, } \\
\text { computer-assisted design, MES, manufacturing execution system, } \\
\text { TIDE, Technology Insertion and Execution Program }\end{array}$} & \multicolumn{2}{|c|}{$\begin{array}{l}\text { 15. NUMBER OF PAGES } \\
31\end{array}$} \\
\hline \multicolumn{5}{|l|}{ 16. PRICECODE } \\
\hline $\begin{array}{l}\text { 17. SECURTY CLASSIFCATION } \\
\text { OF REPORT } \\
\text { Unclassified }\end{array}$ & $\begin{array}{l}\text { 18. SECURTY CLASSIFCATION OF } \\
\text { THSPAGE } \\
\text { Unclassified }\end{array}$ & $\begin{array}{l}\text { 19. SECURTYCLL } \\
\text { ABSTRACT } \\
\text { Unclassifie }\end{array}$ & SIFCATION OF & $\begin{array}{l}\text { 20. LMTATION OF ABSTRACT } \\
\text { UL }\end{array}$ \\
\hline
\end{tabular}

